\title{
Stimulation of Globin Synthesis: Relative Responsiveness of Reticulocytes and Nucleated Erythroid Cells
}

\author{
Herbert S. Waxman \\ From Temple University School of Medicine, \\ Philadelphia, Pennsylvania 19140
}

A в S T RACT The effects of iron, cobalt, hemin, and plasma on hemoglobin synthesis by suspensions of rabbit reticulocytes and nucleated bone marrow cells were studied. L-Leucine- ${ }^{14} \mathrm{C}$ and sodium pyruvate- $3-{ }^{14} \mathrm{C}$ were employed to measure globin and heme synthesis, respectively. Normal plasma (or serum) was found to stimulate the rate of globin synthesis in both systems. The stimulatory effects of iron and hemin were additive to those of plasma or serum only in the reticulocytes.

Cobaltous ion, at concentrations less than $1.0 \mathrm{mmole} /$ liter, was found to stimulate globin synthesis by reticulocytes as effectively as ferrous ion; cobalt was inhibitory only at concentrations greater than 3.0-5.0 mmoles/liter. Heme synthesis by reticulocytes was inhibited at all concentrations employed (0.2-5.0 mmoles/liter).

In bone marrow nucleated erythroid cells, globin synthesis was markedly enhanced by exogenous hemin. In contrast to reticulocytes, however, bone marrow cells were unresponsive to either cobalt or transferrin-bound iron. Possible implications of these findings on regulation of the rate and mechanism of iron uptake and hemoglobin synthesis in vivo are discussed.

\section{INTRODUCTION}

Anemia is frequently observed in chronic inflammatory and neoplastic diseases (1). Failure of iron utilization has been described in these disorders $(2,3)$, and studies of mobilizable iron support this finding (4). A detailed understanding of the pathogenesis of the marrow failure is limited by incomplete knowledge about the normal development and function of the erythroid series and modification of these processes by disease.

Most, if not all, of the hemoglobin of the mammalian erythroid cell is already present by the late nucleated

Dr. Waxman is an Advanced Clinical Fellow of the American Cancer Society.

Received for publication 7 November 1969 and in revised form 22 December 1969. stages (5). Most studies on the control of hemoglobin synthesis have used the more convenient model of the reticulocyte (6), although it is by no means clear that the mechanism of control of globin synthesis is identical or even similar in both nucleated and non-nucleated erythroid cells. A number of compounds have been shown to enhance polyribosome formation and globin synthesis in the reticulocyte; the most physiologic of these stimulating agents are heme and ferrous ion (7-9). Of great interest, because of its ability to enhance erythropoiesis in vivo, has been cobaltous ion $(8,10)$, although its stimulatory effect in vitro has been recently questioned (11).

The present studies were undertaken to investigate further agents stimulatory to globin synthesis, including cobalt. ${ }^{1}$ In addition, the comparative effects of these agents on the rate of globin formation by reticulocytes and nucleated erythroid cells from the bone marrow were to be studied.

\section{METHODS}

Preparation of cell suspensions. New Zealand white rabbits were used as the source of all the cells. Animals to be made anemic by phenylhydrazine were given daily injections of $1.0 \mathrm{ml}$ of $2.5 \%$ neutralized phenylhydrazine for 4 or 5 days and bled by cardiac puncture $48 \mathrm{hr}$ after the last dose. A reticulocytosis greater than $90 \%$ was consistently produced. Iron-deficiency anemia was produced by maintenance on an iron-free diet plus repeated phlebotomy from an ear vein of 10 - to $20-\mathrm{ml}$ aliquots of blood resulting in a hematocrit of less than $30 \%$. Reticulocytes, in each case obtained from an animal given phenylhydrazine, were washed three times with reticulocyte salt solution (RSS: see below) and the buffy coat repeatedly removed by aspiration. The cells were then suspended in an equal volume of RSS before pipetting to the incubation flask, where $0.25 \mathrm{ml}$ of cells was suspended in a total volume of $2.0 \mathrm{ml}$ (12).

Bone marrow cells were obtained from the humeri, femori, and tibiae, as described by Morell, Savoie, and London (13). Unless otherwise noted, the bone marrow was from

${ }^{1}$ In references to metallic cations, "cobalt" will refer to the cobaltous ion and "iron" to the ferrous ion. 
normal rabbits. The cells were collected in RSS in plastic tubes, shaken by hand for $5 \mathrm{~min}$ to yield a single-cell suspension, and centrifuged. The fat layer and supernatant fluid were removed by suction and the cells suspended and washed twice in RSS. The cells were finally suspended in RSS, made up to volume (usually to a density of $50,000-300,000$ nucleated erythroid cells per $\mathrm{mm}^{3}$ ), and filtered through gauze to remove coarse clumps. An aliquot was then removed for cell counts and differential counts of the nucleated cells by standard methods (14).

Incubation of cell suspensions. $0.25 \mathrm{ml}$ aliquots of packed reticulocytes or $0.5 \mathrm{ml}$ aliquots of suspended bone marrow cells were incubated in a total volume of $2.0 \mathrm{ml}$ in $25-\mathrm{ml}$ Erlenmeyer flasks at $37^{\circ} \mathrm{C}$ in room air. The flasks were agitated in a Dubnoff metabolic shaker. The incubations provided a final concentration of glucose or pyruvate of 5.55 mmoles/liter, and tris (hydroxymethyl) aminomethane hydrochloride (Tris) buffer, $\mathrm{pH} \mathrm{7.4,} \mathrm{of} 1.0 \mathrm{mmole} / \mathrm{liter}$, and were carried out in the reticulocyte salt solution (RSS) previously described (12). The nine amino acids found rate limiting in globin synthesis were provided in concentrations recommended by Borsook, Fischer, and Keighley (15). It was ascertained in control experiments that no additional stimulation of globin synthesis by either reticulocyte or bone marrow cells was produced using the larger number of amino acids originally employed by Borsook et al. (15). Solutions of cobalt (as cobaltous chloride), iron (as ferrous ammonium sulfate), and hemin were prepared as previously described (8) and used at the concentrations indicated below. Hemin was present at a final concentration of $0.05 \mathrm{mmole} / \mathrm{liter}$. Unless specifically noted, plasma (or serum) was not present during the isolation and incubation of cell suspensions. When used, the plasma (or serum) was obtained from normal rabbits.

Measurement of rate of globin and heme synthesis. When leucine-1-14C was used to measure globin synthesis, the labeled compound replaced "cold" leucine in the amino acid mixture; $0.5 \mu \mathrm{Ci}$ was present in each flask. When pyruvate$3-{ }^{14} \mathrm{C}$ was employed, $0.5 \mu \mathrm{Ci}$ of the labeled compound and $11.1 \mu$ moles total pyruvate were present in each flask.

To terminate incubation, cold RSS was added to the suspension and the cells centrifuged in the cold. Hemolysis of reticulocytes was carried out as previously described (12). Differential hemolysis of erythroid cells in the bone marrow preparations was effected as described by Morell et al. (13), except that four volumes of $0.0015 \mathrm{M} \mathrm{MgCl}_{2}$ were used for lysis and isotonicity then restored with eight volumes of the buffer employed in the reticulocyte experiments (12). In some studies with bone marrow cells, carrier hemoglobin was added to each tube at this point. In all experiments, samples were then cleared of unlysed cells and particulate material by centrifugation at $100,000 \mathrm{~g}$ for $1 \mathrm{hr}$ in the Spinco ultracentrifuge. When leucine- $1-{ }^{14} \mathrm{C}$ had been used, precipitation of the protein with trichloroacetic acid and subsequent washing were carried out as previously described (12). When labeling was effected with pyruvate- $3-{ }^{14} \mathrm{C}$, the supernatant of the centrifuged cell lysate was extracted with strontium chloride in acetic acid and acetone, according to Labbe and Nishida (16). The heme was precipitated and washed according to these authors. The heme crystals were then dissolved in acetone; an aliquot was transferred to an aluminum planchet, dried, and counted in a NuclearChicago gas flow counter. Colorimetric determination of heme concentration was carried out on another aliquot (17). The precipitated globin was exhaustively washed with the strontium chloride solution until no additional heme could be extracted. The white globin precipitate was then washed as described above for trichloroacetic acid-precipitated hemoglobin. Hemoglobin and globin samples so prepared were weighed and counted in thixotropic gel containing liquid scintillation phosphor, as described by Schwartz and Nathan (18).

Preparation of transferrin-bound iron. Because of the possibility that binding by transferrin of iron was incomplete after only an hour at room temperature, chelated iron was prepared by two additional methods. Bates, Billups, and Saltman (19) showed that binding of iron by transferrin takes place instantaneously in the presence of nitrilotriacetic acid (NTA). $25 \mu$ moles of ferrous ammonium sulfate and $60 \mu$ moles of NTA were dissolved in water, brought to $\mathrm{pH}$ 7.5 with sodium bicarbonate, and made up to $20 \mathrm{ml}$. Rabbit transferrin was dissolved in Tris buffer, 0.1 mole/liter, $\mathrm{pH}$ 7.5 , and brought to a concentration of $20 \mathrm{mg} / \mathrm{ml}$. Aliquots of the two solutions were mixed, allowed to stand at room temperature for $1 \mathrm{hr}$, then dialyzed in the cold against several changes of $0.001 \mathrm{M}$ Tris buffer, $\mathrm{pH} 7.5$, and made up to a final concentration of $1 \mathrm{mg} / \mathrm{ml}$ in isotonic RSS for use in incubations. In an alternate method, $1 \mathrm{ml}$ of a $1.0 \mathrm{~mm}$ solution of ferrous ammonium sulfate in water was added to $3 \mathrm{ml}$ of a solution of $5 \mathrm{mg} / \mathrm{ml}$ transferrin in $0.01 \mathrm{M}$ sodium bicarbonate and the $\mathrm{pH}$ adjusted to 7.0. The solution was allowed to stand $24 \mathrm{hr}$ at $37^{\circ} \mathrm{C}$ and then dialyzed and made up to a final transferrin concentration of $1 \mathrm{mg} / \mathrm{ml}$ as described above.

Hemoglobin chromatography. Chromatography of the centrifuged cell lysate was carried out on columns of carboxymethyl Sephadex C-50 cation exchange resin, according to Winterhalter, Heywood, Huehns, and Finch (20). A column, $17 \times 200 \mathrm{~mm}$, was eluted at room temperature.

Materials. Rabbits were obtained from a commercial breeder. Reagent grade chemicals were used. Amino acids

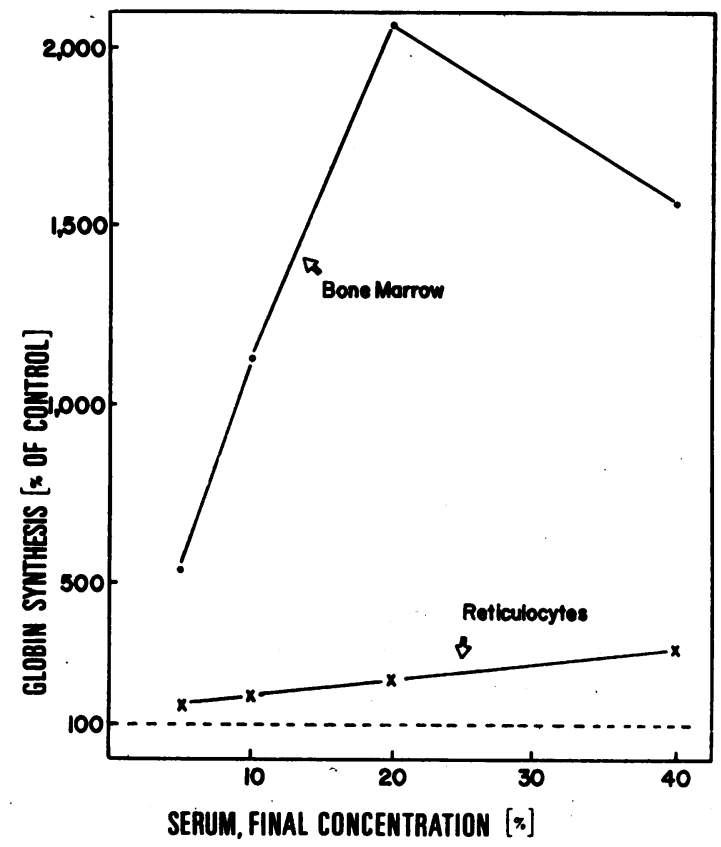

FIgURE 1 Rate of globin synthesis by reticulocytes and bone marrow nucleated erythroid cells as a function of final concentration of plasma. Globin synthesis is expressed as per cent of the rate in identical flasks without plasma. 


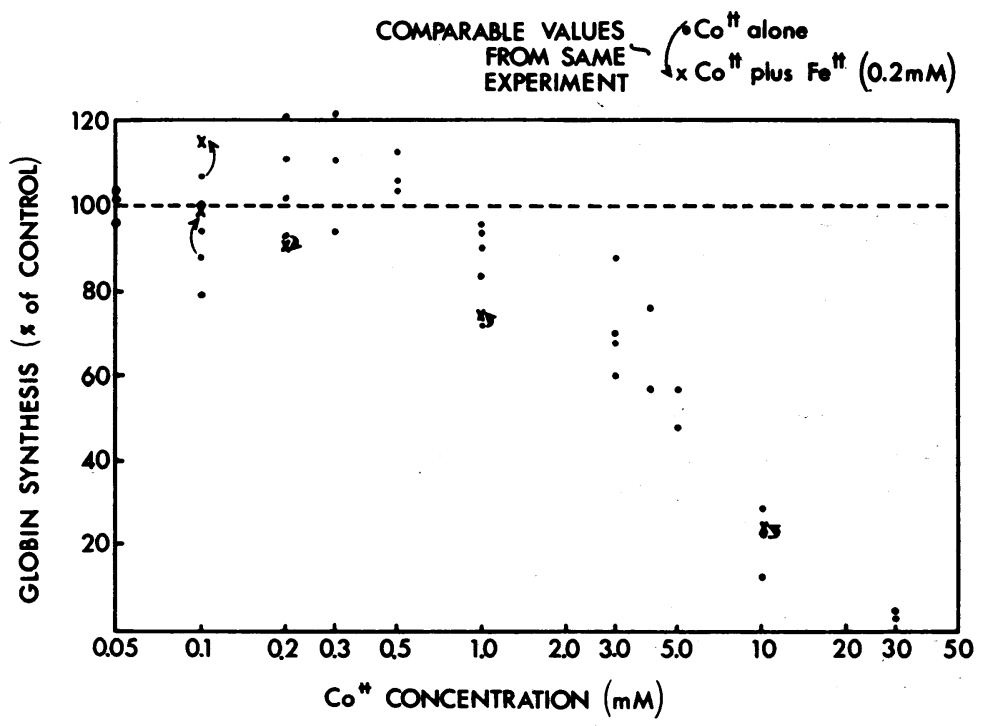

FIGURE 2 Rate of globin synthesis by reticulocytes as a function of concentration of cobalt. Control flasks were incubated with $0.2 \mathrm{~mm}$ iron. - represents result with cobalt, at a concentration indicated; $X$ represents result with cobalt, at the concentration indicated, plus $0.2 \mathrm{mM}$ iron in the same flask. The arrows connect values from identical cobalt-containing flasks incubated with and without iron in the same experiment.

and sodium pyruvate were obtained from Calbiochem. Rabbit transferrin was purchased from the Pentex Division of Miles Labs., Inc. Recrystallized hemin and nitrilotriacetic acid were obtained from Eastman Organic Chemicals, Rochester, N. Y. Leucine- $1-{ }^{14} \mathrm{C}(25.6 \mathrm{mCi} / \mathrm{mmole})$ and pyruvate-3- ${ }^{14} \mathrm{C}(3.06 \mathrm{mCi} / \mathrm{mmole})$ were purchased from New England Nuclear Corp. CM-Sephadex C-50 was a product of Pharmacia Fine Chemicals, Inc. Low iron rabbit diet was purchased from General Biochemicals.

\section{RESULTS}

Effect of plasma and serum on. hemoglobin synthesis by reticulocytes and bone marrow nucleated erythroid cells. Normal rabbit plasma or serum, in final concentrations of $5-40 \%$, stimulated the incorporation of leucine $-{ }^{14} \mathrm{C}$ into globin by reticulocytes and normal bone marrow erythroid cells (except that the latter seemed to be maximally stimulated at $20 \%$ concentration, Fig. 1). Globin synthesis by reticulocytes was also stimulated by iron or hemin, as previously described (7). The stimulation by normal plasma or serum was additive to that of hemin or iron (Table I). In contrast to reticulocytes, bone marrow cells stimulated by plasma had little or no capacity to respond further to irontransferrin or hemin (Table II). The greater stimulation of globin synthesis by hemin compared to iron was an unexpected but consistent observation and will be discussed further below.. In all the above experiments, normal plasma and serum were seen to behave similarly. Counts of nucleated cells were unchanged by any of the experimental conditions.
Effect of cobaltous chloride on hemoglobin synthesis by reticulocytes. By use of leucine $-{ }^{14} \mathrm{C}$, which is incorporated only into the globin moiety of hemoglobin, as a measure of hemoglobin synthesis, previous findings of stimulation $(8,15)$ were confirmed. In concentrations of less than $1.0 \mathrm{mmole} / \mathrm{liter}$, cobalt enhanced the rate of globin synthesis, compared to control flasks without the metal. Even in concentrations as low as 0.05 mmole/ liter stimulation was frequently seen. Similar effects were noted with iron. ${ }^{2}$ Inhibition of globin synthesis was not seen at concentrations of either metal below 1.0-3.0 mmoles/liter.

As noted previously (7), cells from different rabbits vary in their capacity to respond to such stimulatory agents as iron or cobalt (or hemin). In Fig. 2, therefore, the effect of cobalt on globin formation is compared with the rate of synthesis in cells from the same animal in the presence of iron at a final concentration of $0.2 \mathrm{mmole} / \mathrm{liter}$. Thus, each point in the figure is compared to a control incubation of the same cells with iron at a maximally stimulatory concentration. It is apparent that, at concentrations of $0.05-0.5 \mathrm{mmole} /$ liter, cobalt is consistently at least as effective as iron. On the other hand, at cobalt concentration of $1.0 \mathrm{mmole} /$ liter, maximum rate of globin synthesis by reticulocytes is not achieved. As noted above, only at concentration

\footnotetext{
${ }^{2}$ At the concentrations used, iron alone has been shown to be as effective as iron plus transferrin in stimulating globin synthesis by rabbit reticulocytes (7).
} 
of 3.0 mmoles/liter or higher is cobalt actually inhibitory. It was also shown (Fig. 2) that stimulation of globin synthesis by cobalt and iron together in the same flask was not significantly greater than by either metal alone.

In some experiments with reticulocytes, pyruvate- $3-{ }^{14} \mathrm{C}$ was used to measure both heme and globin synthesis. Iron stimulated both heme and globin synthesis, while cobalt inhibited the former and enhanced the latter ( $\mathrm{Ta}$ ble III). In these experiments, pyruvate, at a final concentration of $5.55 \mathrm{mmoles} /$ liter, replaced the glucose usually present. In a similar experiment, cobalt $(0.2$ mmole/liter) enhanced the rate of globin synthesis to $142 \%$ of the control value, whereas hemin stimulated synthesis to $149 \%$. It should be noted that these incubations took place in the absence of plasma or serum.

Comparative effect of iron, cobalt, and hemin on globin synthesis in reticulocytes and bone marrow erythroid cells. Having confirmed that cobalt (as well as iron) is indeed stimulatory to globin synthesis in reticulocytes, attention was directed to the nucleated erythroid cell derived from normal rabbit bone marrow. In striking contrast to the effect in the reticulocyte, globin synthesis by the nucleated red cell was not stimulated by either iron or cobalt, even in the presence of rabbit transferrin (Fig. 3). Because of the possibility that saturation of the iron-binding capacity of transferrin had not been effected by the usual preparation in RSS, transferrin-bound iron was prepared in the presence of nitrilotriacetic acid or sodium bicarbonate (see Methods). Over the range $50-200 \mathrm{mg}$ saturated transferrin per $\mathrm{ml}$, these complexes (alone or with additional ferrous ion at a final concentration of $0.1-0.2 \mathrm{mmole} /$ liter) were ineffective in enhancing the rate of globin synthesis. The same preparations were, however, normally stimulatory to globin formation in reticulocytes. In contrast to the relative ineffectiveness of cobalt or iron, hemin had a marked effect on globin synthesis in

TABLE I

Stimulation of Globin Synthesis by Phenylhydrazine-Produced Reticulocytes in the Presence or Absence of Plasma

\begin{tabular}{lcc}
\hline & \multicolumn{2}{c}{$\begin{array}{c}\text { Rate of globin synthesis } \\
\text { (\% of control) }\end{array}$} \\
\cline { 2 - 3 } Addition to incubation medium & No plasma & $10 \%$ Plasma \\
\hline & \multicolumn{3}{c}{$\%$} \\
None & 100 & 181 \\
Fe $^{++}(0.1$ mmole/liter $)$ & 288 & 455 \\
Iron-transferrin* & 279 & 426 \\
Hemin & 271 & 444 \\
\hline
\end{tabular}

* In this and subsequent tables, "iron-transferrin" refers to a final concentration of $0.2 \mathrm{mM}$ ferrous ammonium sulfate plus $50 \mathrm{mg} / \mathrm{ml}$ iron-saturated transferrin in the incubation flask.
TABLE II

Stimulation of Globin Synthesis by Bone Marrow Nucleated Erythroid Cells in the Presence or Absence of Plasma or Serum

\begin{tabular}{lcc}
\hline & \multicolumn{2}{c}{$\begin{array}{c}\text { Rate of globin synthesis } \\
(\% \text { of control) }\end{array}$} \\
\cline { 2 - 3 } Addition to incubation medium & Control & $20 \%$ Plasma \\
\hline None & 100 & 424 \\
Iron-transferrin & 96 & 455 \\
Hemin & 240 & 473 \\
\hline
\end{tabular}

nucleated erythroid cells (Fig. 3). The bone marrow cells from one of the rabbits made anemic and iron deficient by iron-free diet and repeated phlebotomy did respond to iron $(193 \%)$; the effect of hemin on the same cells was correspondingly greater $(673 \%$; see Fig. 3 ). Reticulocytes from the same animal, in contrast to the bone marrow cells, were stimulated almost equally well by iron, cobalt, or hemin $(155 \%, 151 \%$, and $223 \%$, respectively, compared to control values for the reticulocytes). It should be noted that the rate of globin synthesis per cell by the normal bone marrow nucleated erythroid cells was five- to tenfold greater than that of reticulocytes derived from phenylhydrazine-treated rabbits.

Fig. 3 shows the effect of iron, cobalt, and hemin on the rate of globin synthesis in bone marrow nucleated red cells from a number of animals. The differences between the effects of iron vs. hemin or cobalt vs. hemin are very significant $(P<0.001$ and $P<0.01$, respectively). The effects of iron and cobalt did not differ significantly $(P>0.1) .^{3}$

Chromatography on CM-Sephadex C-50 was carried out on the lysate of bone marrow erythroid cells which had been incubated with and without hemin. In each case, $90 \%$ of the total $\mathrm{E}_{220}$-absorbing material and $100 \%$ of the Esw-absorbing material was recovered in the second (hemoglobin) peak. In the presence of hemin, the total counts and the specific activity of the material recovered from the hemoglobin peak were more than threefold those seen in the absence of hemin. On the other hand, both the total counts and specific activity in the first (non-heme protein) peak were increased less than $40 \%$. In the absence of hemin, the counts in the first peak represented $19 \%$ of these recovered from the column; in the lysate from cells incubated with hemin, the comparable value was $11 \%$. It was thus demonstrated that at least $80 \%$ of the radioactivity in the lysates was chromatographically identifiable as hemoglobin. Moreover, it was the specific activity of the hemoglobin ra-

\footnotetext{
${ }^{3}$ These probabilities were determined from the $t$ test for small samples (41).
} 
dioactivity that was so greatly stimulated by hemin. The over-all counts and changes in the non-heme protein peak were minor.

\section{DISCUSSION}

Control of the rate of hemoglobin synthesis has been intensively studied $(6,9,21)$. A necessary event for globin synthesis is the formation of the polyribosome from its constituents: ribosomes and the putative messenger RNA. Polyribosome assembly is enhanced by some agents stimulatory to globin synthesis, including iron, cobalt, and heme $(7,8,10)$. Iron is effective only insofar as it promotes synthesis of intracellular heme; the latter is the actual mediator of polyribosome formation (8):

The effects of other agents known to stimulate hemoglobin synthesis are less clear. It has been observed that plasma and serum enhance the formation of heme (22, 23) and globin (24) in reticulocytes and bone marrow cells. The stimulatory activity of plasma has been variably characterized as heat-stable (24), heat-labile (23), and fully substituted for by iron-transferrin (15).

In the present studies, the effects of normal plasma or serum could not be duplicated by increasing the con-

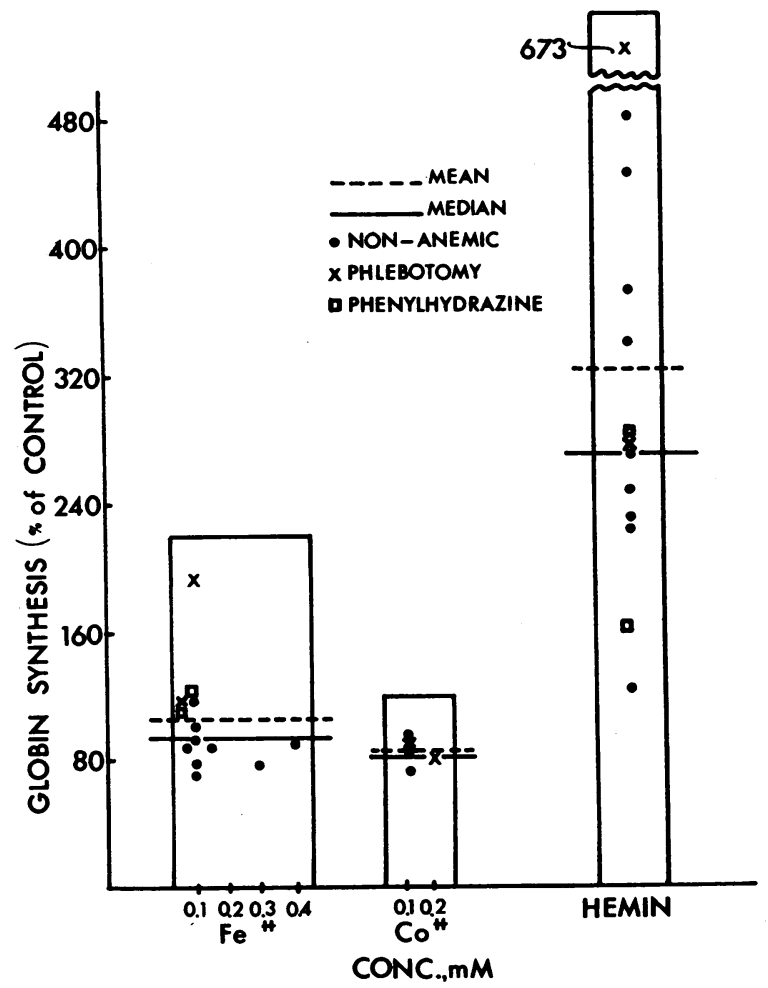

FIGURE 3 Rate of globin synthesis by bone marrow nucleated erythroid cells incubated with iron, cobalt, or hemin, as indicated. Globin synthesis is expressed as per cent of the rate in identical flasks without iron, cobalt, or hemin.
TABLE III

Effect of Iron or Cobalt on the Rate of Synthesis of Globin and Heme from Pyruvate-3-14C by Reticulocytes

\begin{tabular}{lcc}
\hline & \multicolumn{2}{c}{$\begin{array}{c}\text { Rate of synthesis } \\
\text { (\% of control) }\end{array}$} \\
\cline { 2 - 3 } Addition to incubation medium & Globin & Heme \\
\hline None & 100 & 100 \\
$\mathrm{Fe}^{++}, 0.1 \mathrm{mmole} / \mathrm{liter}$ & 124 & 136 \\
$\mathrm{Co}^{++}, 0.2 \mathrm{mmole} / \mathrm{liter}$ & 129 & 70 \\
$\mathrm{Co}^{++}, 1.0 \mathrm{mmole} / \mathrm{liter}$ & 136 & 51 \\
$\mathrm{Co}^{++}, 5.0 \mathrm{mmoles} / \mathrm{liter}$ & 86 & 18 \\
\hline
\end{tabular}

centration of either iron-transferrin or hemin as much as fivefold. It is therefore unlikely that the iron (or hemin) content or the iron-binding capacity of plasma account for its entire effect.

In contrast to the findings in reticulocytes, irontransferrin or hemin had no effect additive to that of plasma when normal bone marrow cells were employed. Moreover, the degree of enhancement by serum was considerably greater on nucleated erythroid cells. It is of interest that human bone marrow cells in vitro have been reported to respond to erythropoietin with increased synthesis of heme (25). Whether the factor responsible for the striking enhancement of globin synthesis in the present studies is erythropoietin and (or) another plasma constituent remains to be determined.

Cobalt has been shown to stimulate erythropoiesis, both in vivo (26) and in vitro $(8,10,13,15)$. In a recent report, globin synthesis by reticulocytes and bone marrow cells has been shown to be inhibited by cobalt (11). In that study, however, the cells were derived from animals treated with parenteral iron and were incubated in the presence of bovine serum albumin and additional ferrous ion. What effect was introduced by these variations in experimental design is not known.

In the present study, reticulocytes from rabbits made anemic by phlebotomy or phenylhydrazine did respond to cobalt. Globin synthesis, measured by the incorporation of leucine ${ }^{14} \mathrm{C}$ into protein, was stimulated as much as twofold by concentrations of cobalt below $1 \mathrm{mmole} /$ liter. Iron was no more and, in some cases, was less effective than cobalt. At higher concentrations, however, cobalt did indeed inhibit globin synthesis. It is of interest that, at comparable concentrations of cobalt, oxidation of $\alpha$-keto carboxylic acids has been shown to be inhibited in rat liver mitochondria (27) and bacteria (28).

Even at the low concentrations stimulatory to globin synthesis, cobalt inhibited heme production. To avert the possible error that might be introduced into measurement of heme synthesis if ${ }^{14} \mathrm{C}$-labeled glycine were 
to be diluted by endogenously produced amino acid (11, $13,22)$, the present study employed pyruvate- $3{ }^{14} \mathrm{C}$, a precursor of both glycine and succinic acid. By this method, inhibition of heme synthesis has been confirmed. Cobalt has been reported to inhibit tetrapyrrole synthesis before uroporphyrinogen formation (29). The mechanism of the stimulation of globin synthesis by the metal is completely unknown. No cobalt-containing "hemoglobin" has been described. However, cobaltprotoporphyrin has been shown to stimulate globin synthesis (29a). The avidity of transferrin for cobalt (30) raises the possibility that cobalt may displace iron from the cell surface into the cytoplasm of the reticulocyte, but no evidence bearing on this hypothesis is available.

In bone marrow nucleated erythroid cells, globin synthesis was not stimulated by cobalt, as noted by Borsook, Deasy, Haagen-Smit, Keighley, and Lowy (31) but in contrast to the findings of Morell et al. (13). Whether this discrepancy may be ascribed to the fact that Morell et al. isolated the marrow cells in autologous plasma remains to be determined.

The failure of bone marrow cells to respond to amounts of iron-transferrin stimulatory to globin synthesis in reticulocytes is of interest. There is evidence that much of the iron utilized in vivo for hemoglobin synthesis is derived from circulating iron-transferrin (summarized by Katz [32]). The entry of such iron into bone marrow cells $(33,34)$, and reticulocytes $(32,35)$ has been demonstrated in vitro. A variable proportion of the iron entering the cell in vitro has been found to be incorporated into heme (and, by inference, into hemoglobin) $(36,37)$. A study comparing the fate of ${ }^{50} \mathrm{Fe}$ presented to the marrow in vivo and in vitro showed strikingly greater utilization for heme synthesis of the iron captured by the cell in vivo (37). It is apparent, of course, that measurement of hemoglobin synthesis from ${ }^{50} \mathrm{Fe}$ ignores the contribution to the rate of hemoglobin formation from the endogenous, unlabeled iron of the cell.

It has also been shown $(30,35)$ that the entry of iron into the reticulocyte is by no means absolutely dependent on transferrin, although specificity of uptake by the reticulocyte is seen only in the presence of the ironbinding protein (30). The rate of transferrin-mediated iron entry into rabbit reticulocytes (31) would be just adequate to support the observed rate of hemoglobin synthesis (12). The greater capacity of nucleated red cells to take up iron (34) would parallel the more rapid rate of globin synthesis by the marrow red cell precursor compared to the reticulocyte. The failure of complete utilization of the iron for hemoglobin synthesis (37) raises questions as to what proportion of this capacity is actually realized, however. The present finding of lack of stimulation of bone marrow globin synthesis by irontransferrin also supports the possibility of an alternate route of functional iron entry. It should be noted that, in contrast to studies employing ${ }^{50} \mathrm{Fe}$, the present results represent total globin synthesis. (Borsook et al. [31] have shown that there is little if any dilution of amino acid label by endogenous cellular amino acids. Thus leucine- ${ }^{14} \mathrm{C}$ incorporation does indeed measure total globin synthesis.)

In contrast to iron, hemin stimulates globulin synthesis in bone marrow nucleated erythroid cells (as it does in reticulocytes). That heme serves not merely as a means of facilitating entry of inorganic iron into cells has been established (8). Indeed, heme seems actually to inhibit iron uptake from plasma by reticulocytes (38). It is likely, therefore, that in the marrow nucleated erythroid cell, heme directly stimulates globin synthesis. If so, one interpretation of the lack of effect of irontransferrin is inadequate uptake of iron to support maximum rates of globin synthesis under the experimental conditions. Insufficient endogenous heme formation is an alternative possibility.

The reservations noted above about transferrin-bound iron as sole source of cellular iron for hemoglobin synthesis imply that an alternate mode of iron uptake may be important. Such a process has been observed by Bessis and Breton-Gorius (39). Termed "rhopheocytosis," it describes the uptake by pinocytosis of iron-containing granules from the cytoplasm of reticulum cells by erythroid cells in the bone marrow. If such a mechanism is indeed of physiologic importance, a block in rhopheocytosis could account for the anemia of inflammation and neoplasia, in which excess stainable iron in marrow reticulum cells appears despite reduced numbers of sideroblasts (1). A congenital hypochromic microcytic anemia is also explainable in terms of impaired rhopheocytosis (40). The exact role of the ingestion process in erythropoiesis remains to be established, however. There exist significant pieces of indirect evidence against the primacy of this process in the transfer of iron to nucleated red cell precursors (32).

Unresolved by the present study is the nature of the substance(s) in plasma responsible for globin synthesis. Also unanswered is the reason for the lack of response of bone marrow nucleated erythroid cells to iron-transferrin whereas their response to hemin is significant. These questions are presently under investigation.

\section{ACKNOWLEDGMENTS}

The skilled technical assistance of the Misses Sandra Stogo and Martha Turner is gratefully acknowledged.

This work was supported by a grant from the Life Insurance Medical Research Fund and by Institutional grants to Temple University from the American Cancer Society and the National Institutes of Health. 


\section{REFERENCES}

1. Wintrobe, M. M. 1967. Clinical Hematology. Lea \& Febiger, Philadelphia. 6th edition. 758-765.

2. Freireich, E. J., A. Miller, C. P. Emerson, and J. F. Ross. 1957. The effect of inflammation on the utilization of erythrocyte and transferrin bound radioiron for red cell production. Blood. 12: 972.

3. Miller, A., R. B. Chodos, C. P. Emerson, and J. F. Ross. 1956. Studies of the anemia and iron metabolism in cancer. J. Clin. Invest. 35: 1248.

4. Wardle, E. N., and M. C. G. Israels. 1968. The differential ferrioxamine test in rheumatoid disease, neoplastic and other hematological disorders. Brit. J. Haematol. $14: 5$.

5. Borsook, H., D. Teigler, and A. Gunderson. 1968. Studies on erythropoiesis. Arch. Biochem. Biophys. 125: 429.

6. Sargent, J. R. 1968. Biosynthesis of specific proteins in mammalian systems. In Techniques in Protein Biosynthesis. Chapter 3. P. N. Campbell and J. R. Sargent, editors. Academic Press Inc., New York.

7. Waxman, H. S., and M. Rabinovitz. 1965. Iron supplementation in vitro and the state of aggregation and function of reticulocyte ribosomes in hemoglobin synthesis. Biochem. Biophys. Res. Commun. 19: 538.

8. Waxman, H. S., and M. Rabinovitz. 1966. Control of reticulocyte polyribosome content and hemoglobin synthesis by heme. Biochim. Biophys. Acta. 129: 369.

9. Waxman, H. S., M. L. Freedman, and M. Rabinovitz. 1967. Studies with ${ }^{59} \mathrm{Fe}$-labeled hemin on the control of polyribosome formation in rabbit reticulocytes. Biochim. Biophys. Acta. 145: 353.

10. Grayzel, A. I., P. Horchner, and I. M. London. 1966. The stimulation of globin synthesis by heme. Proc. Nat. Acad. Sci. U.S. A. 55: 650 .

11. Schulman, H. M., and A. Jobe. 1968. The inhibition of heme and globin synthesis by cobalt in rabbit reticulocytes and bone marrow. Biochim. Biophys. Acta. 169: 241.

12. Rabinovitz, M., and H. S. Waxman. 1965. Dependence of polyribosome structure in reticulocytes on iron; implication on the tape theory of haemoglobin synthesis. Nature (London). 206: 897.

13. Morell, H., J. C. Savoie, and I. M. London. 1958. The biosynthesis of heme and the incorporation of glycine into globin in rabbit bone marrow in vitro. J. Biol. Chem. 233 : 923.

14. Cartwright, G. E. 1968. Diagnostic Laboratory Hematology. Grune \& Stratton Inc., New York. 4th edition.

15. Borsook, H., E. H. Fischer, and G. Keighley. 1957. Factors affecting protein synthesis in vitro in rabbit reticulocytes. J. Biol. Chem. 229: 1059.

16. Labbe, R. F., and G. Nishida. 1957. A new method of hemin isolation. Biochim. Biophys. Acta. 26: 437.

17. Falk, J. E. 1964. Porphyrins and Metalloporphyrins. Elsevier Publishing Company, New York. 181.

18. Schwartz, E., and D. G. Nathan. 1967. New methods of counting of $\mathrm{C}^{14}$-labeled hemoglobin and hemin. J. Lab. Clin. Med. 70: 841 .

19. Bates, G. W., C. Billups, and P. Saltman. 1967. The kinetics and mechanism of iron (III) exchange between chelates and transferrin. J. Biol. Chem. 242: 2810.

20. Winterhalter, K. H., J. D. Heywood, E. R. Huehns, and C. A. Finch. 1969. The free globin in human erythrocytes. Brit. J. Haematol. 16: 523.

21. Tavill, A. S., A. I. Grayzel, I. M. London, M. K. Williams, and G. A. Vanderhoff. 1968. The role of heme in the synthesis and assembly of hemoglobin. J. Biol. Chem. $243: 4987$.

22. Kassenaar, A., H. Morell, and I. M. London. 1957. The incorporation of glycine into globin and the synthesis of heme in vitro in duck erythrocytes. J. Biol. Chem. 229: 423.

23. Thomas, E. D. 1955. In vitro studies of erythropoiesis. Blood. 10: 600 .

24. Borsook, H., C. L. Deasy, A. J. Haagen-Smit, G. Keighley, and P. H. Lowy. 1952. Incorporation in vitro of labeled amino acids into proteins of rabbit reticulocytes. J. Biol. Chem. 196: 669.

25. Krantz, S. B., O. Gallien-Lartigue, and E. Goldwasser. 1963. The effect of erythropoietin upon heme synthesis by marrow cells in vitro. J. Biol. Chem. 238: 4085.

26. Smith, E. L. 1962. Cobalt. In Mineral Metabolism. Chapter 31. C. L. Comar and F. Bronner, editors. Academic Press Inc., New York.

27. Dingle, J. T., and M. Webb. 1963. Inhibition of pyruvate metabolism in mitochondrial suspensions by cobalt. $\mathrm{Na}$ ture (London). 200 : 1208.

28. Armstrong, M., and M. Webb. 1967. The reversal of phenylarsenoxide inhibition of keto acid oxidation in mitochondrial and bacterial suspensions by lipoic acid and other disulphides. Biochem. J. 103: 913.

29. Eriksen, L., N. Eriksen, and S. Haavaldsen. 1961. The effect of cobalt ions on the biosynthesis of hemoglobin by rabbit reticulocytes in vitro. Acta Physiol. Scand. 53: 300 .

29a. Adamson, S. D., E. Herbert, and S. F. Kemp. 1969. Effects of hemin and other porphyrins on protein synthesis in a reticulocyte lysate cell-free system. J. Mol. Biol. 42 : 247.

30. Jandl, J. H., J. K. Inman, R. L. Simmons, and D. W. Allen. 1959. Transfer of iron from serum iron-binding protein to human reticulocytes. J. Clin. Invest. 38: 161.

31. Borsook, H., C. L. Deasy, A. J. Haagen-Smit, G. Keighley, and P. H. Lowy. 1950. Incorporation in vitro of labeled amino acids into bone marrow cell proteins. $J$. Biol. Chem. 186: 297.

32. Katz, J. H. 1965. The delivery of iron to the immature red cell. Ser. Haematol. 6 : 15.

33. Lajtha, L. G., and H. D. Suit. 1955. Uptake of radioactive iron $\left({ }^{\circ} \mathrm{Fe}\right)$ by nucleated red cells in vitro. Brit. J. Haematol. 1 : 55.

34. Myhre, E. 1964. Iron uptake by human erythroid cells in vitro. Scand. J. Clin. Lab. Invest. 16: 201.

35. Morgan, E. H., and C. B. Laurell. 1962. Studies on the exchange of iron between transferrin and reticulocytes. Brit. J. Haematol. 9 : 471.

36. Clark, P., and R. J. Walsh. 1959. Synthesis of haem by circulating blood cells. Nature (London). 184: 1730.

37. Myhre, E. 1964. Iron uptake and hemoglobin synthesis by human erythroid cells in vitro. Scand. J. Clin. Lab. Invest. 16: 212.

38. Ponka, P., and J. Neuwirt. 1969. Regulation of iron entry into reticulocytes. Blood. 33: 690 .

39. Bessis, M. C., and J. Breton-Gorius. 1962. Iron metabolism in the bone marrow as seen by electron microscopy. Blood. 19: 635 .

40. Shahidi, N. T., D. G. Nathan, and L. K. Diamond. 1964. Iron deficiency anemia associated with an error of iron metabolism in two siblings. J. Clin. Invest. 43: 510.

41. Bancroft, H. 1957. Introduction to Biostatistics. Paul B. Hoeber, Inc., New York. Chapter 15. 